\title{
Serum leptin concentrations in relation to pubertal development
}

\author{
Björn Carlsson, Carina Ankarberg, Sten Rosberg, Ensio Norjavaara, \\ Kerstin Albertsson-Wikland, Lena M S Carlsson
}

Research Centre for Endocrinology and Metabolism, Department of Internal Medicine B Carlsson

L M S Carlsson

International Paediatric Growth Research Centre, Department of Paediatrics,

Sahlgrenska University Hospital, University of Gothenburg, Sweden

C Ankarberg

S Rosberg

E Norjavaara

K Albertsson-Wikland

Correspondence to: Professor Kerstin Albertsson-Wikland, International Pediatric Growth Research Centre, Department of Pediatrics, Sahlgrenska University Hospital, East, University of Gothenburg, S-416 85 Gothenburg, Sweden.

Accepted 18 July 1997

Table 1 Precision of the leptin radioimmunoassay

\begin{tabular}{lllll}
\hline & Sample 1 & Sample 2 & Sample 3 & Sample 4 \\
\hline Mean $(\mu \mathrm{g} / 1)$ & 1 & 3 & 7 & 15 \\
Intra-assay precision & - & 16 & - & 16 \\
$\quad$ Replicates & - & 7.0 & - & 4.9 \\
$\quad$ CV $(\%)$ & 4 & 5 & 4 & 5 \\
$\quad$ Interassay precision & 4.0 & 9.5 & 5.2 & 2.3 \\
$\quad$ RV $(\%)$ & & & & \\
\hline
\end{tabular}

$\mathrm{CV}$, coefficient of variation. ment is well established. ${ }^{12}$ A threshold level of body fat has been proposed to be required for both the initiation of puberty and the maintenance of fertility in women. ${ }^{1}$ These observations suggest that there may be an interaction between adipose tissue and the hypothalamicpituitary-gonadal axis which ensures sufficient energy supplies during pregnancy and lactation. Leptin, a recently identified hormone derived from adipocytes which is encoded by the ob gene, ${ }^{3}$ is an attractive candidate for mediating this effect.

The administration of recombinant leptin to mice reduces their body weight by decreasing their appetite and increasing energy expenditure. ${ }^{4-6}$ In addition to its role in the regulation of body weight, leptin appears to be of critical importance for normal function of the hypothalamic-pituitary-gonadal axis. Female ob/ob mice, which lack bioactive leptin due to a mutation in the coding region of the ob gene, remain prepubertal and are infertile. ${ }^{7}$ Administration of recombinant leptin renders the female ob/ob mice fertile and continued leptin treatment is required to maintain fertility. ${ }^{7}$ Reduction of serum leptin concentrations, induced by starvation, in mice with an intact ob gene also inhibited the pituitarygonadal axis, an effect that was reversed by the administration of recombinant leptin. ${ }^{8}$ Leptin also triggers maturation of the reproductive tract in prepubertal mice. ${ }^{9}$ Thus it appears that leptin is required for both pubertal development and the maintenance of fertility in mice.

The role of leptin in human physiology is less well established. Some studies have shown that leptin is present in human serum and that its concentration correlates with the amount of body fat in adults and children. ${ }^{10}{ }^{11}$ Leptin has been proposed to affect the regulation of pubertal development in humans. ${ }^{12}$ To increase our understanding of the relation between adipose tissue and pubertal development in humans, we measured serum concentrations of leptin in a large number of samples from healthy boys and girls at all stages of puberty.

\section{Subjects and methods} SUBJECTS

A total of 252 healthy children (168 boys, 203 samples; 84 girls, 113 samples) was 


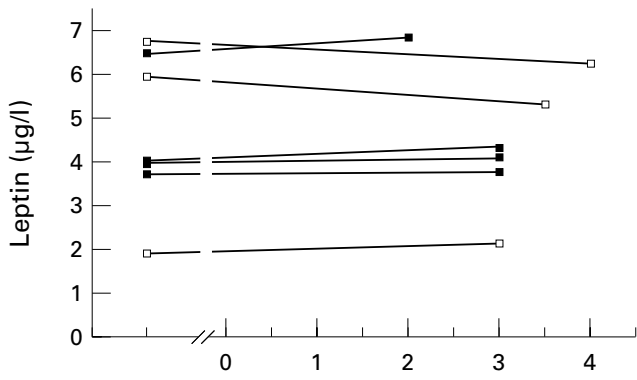

Reference sample Approximate storage time (stored at $-70^{\circ} \mathrm{C}$ ) at $-20^{\circ} \mathrm{C}$ (years)

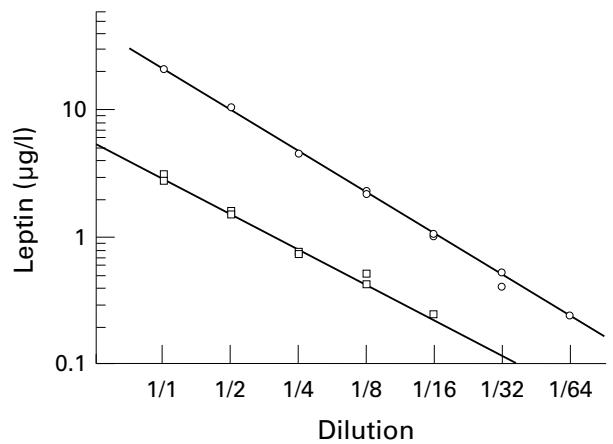

Figure 1 Upper panel: effect of storage conditions and freezing and thawing on serum leptin concentrations. Leptin concentrations were measured in two separate aliquots of seven different samples, one of which had been stored at $-70^{\circ} \mathrm{C}$ and the other at $-20^{\circ} \mathrm{C}$ for several years. None of the $-70^{\circ} \mathrm{C}$ samples had been thawed before analysis, whereas four of the $-20^{\circ} \mathrm{C}$ samples had been thawed at least once during that time. Open symbols represent samples that were kept frozen and closed symbols represent samples that were thawed at least once during the storage period. Lower panel: leptin concentrations in two serially diluted samples from patients.

investigated on one or more occasions at the Children's Hospital, Gothenburg, Sweden. Their chronological ages ranged from 1.7 to 18.6 years and their bone ages were within two SD scores for chronological age. All the children were healthy and well nourished and they had normal thyroid, liver, and kidney

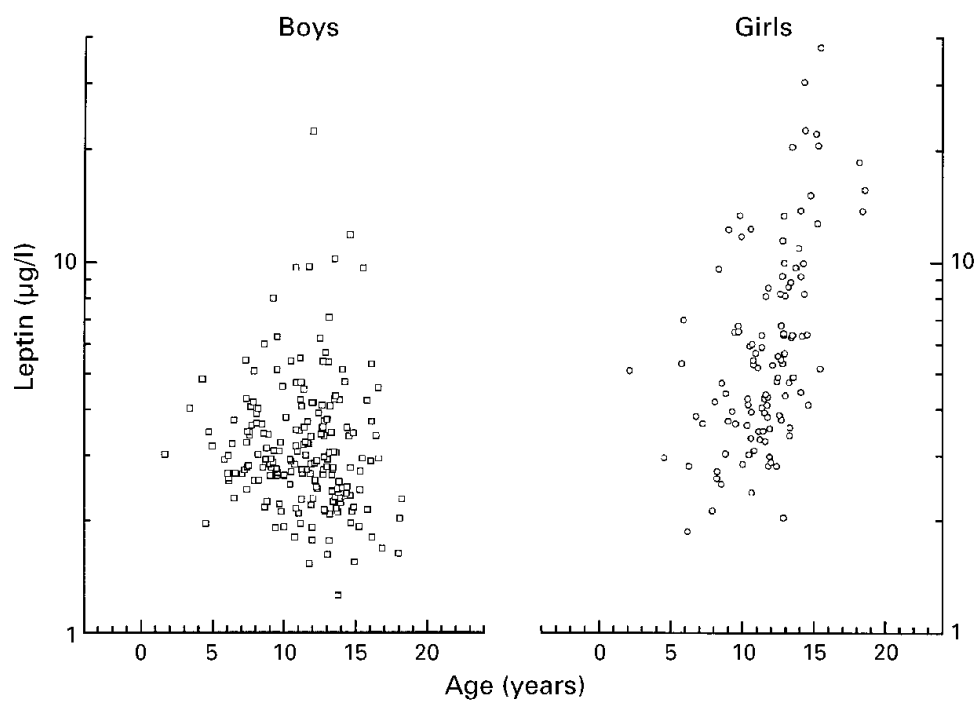

Figure 2 Serum leptin concentrations in 168 boys and 84 girls plotted against age. functions. Children with coeliac disease were excluded. No child was receiving medical treatment.

The study protocol was approved by the ethical committee of the medical faculty, University of Gothenburg. Informed consent was obtained from the children, if old enough, and their parents.

Of the 203 samples from the boys, 124 were taken at the prepubertal stage, 38 at pubertal stage 2,16 at stage 3,12 at stage 4 , and 13 at stage 5 . Of the 113 samples from the girls, 43 were taken at the prepubertal stage, 20 at pubertal stage 2, 20 at stage 3,17 at stage 4, and 13 at stage 5 . Puberty was assessed by pubic hair and breast development according to Tanner and Whitehouse ${ }^{13}$ and by testicular volume according to Zachmann et al. ${ }^{14}$ When adrenarche and gonadarche differed, the pubertal stage was rated according to the development of gonadarche-that is, breast development in girls and testicular volume in boys. Height and weight were converted into SD scores using the Swedish growth reference values for healthy children. ${ }^{15}$ The growth of the children has been followed up since birth and their heights ranged from -5.0 to +5.1 SD scores. Body composition was expressed as a weight for height SD score (range -3.3 to +5.5 , with 22 children outside 2 SD score of the mean) and body mass index (BMI; $\mathrm{kg} / \mathrm{m}^{2}$ ) (range 12.7-27.7) - that is, the subjects were leaner than North American children. ${ }^{16}{ }^{17}$

\section{STUDY PROTOCOL}

The relation between leptin and pubertal development was analysed in a retrospective study. To minimise the influence of the diurnal variation in serum leptin concentrations ${ }^{18}$ all samples were obtained between 10 am and 2 pm.

Cross sectional study

Single samples were obtained from each child.

Longitudinal study

A subgroup of 15 girls, with known dates for menarche, were followed up longitudinally with two to seven repeated observations for each girl.

Leptin radioimmunoassay

Serum leptin concentrations were determined in duplicate by radioimmunoassay (Human Leptin RIA Kit, Linco Research, St Charles, MO, USA). The lower limit of detection (sensitivity) was $0.2 \mu \mathrm{g} / 1$ as defined by Rodbard. ${ }^{19}$ Table 1 gives the intra-assay and interassay precision. The assay was linear down to the detection limit, as tested by the serial dilution of patient samples (fig 1, lower panel).

\section{Sample storage}

Because of the retrospective nature of the study, the effects of freezing and thawing and sample storage conditions on the measured leptin concentrations were tested (fig 1, upper panel). Leptin concentrations were measured in two separate aliquots of seven different 

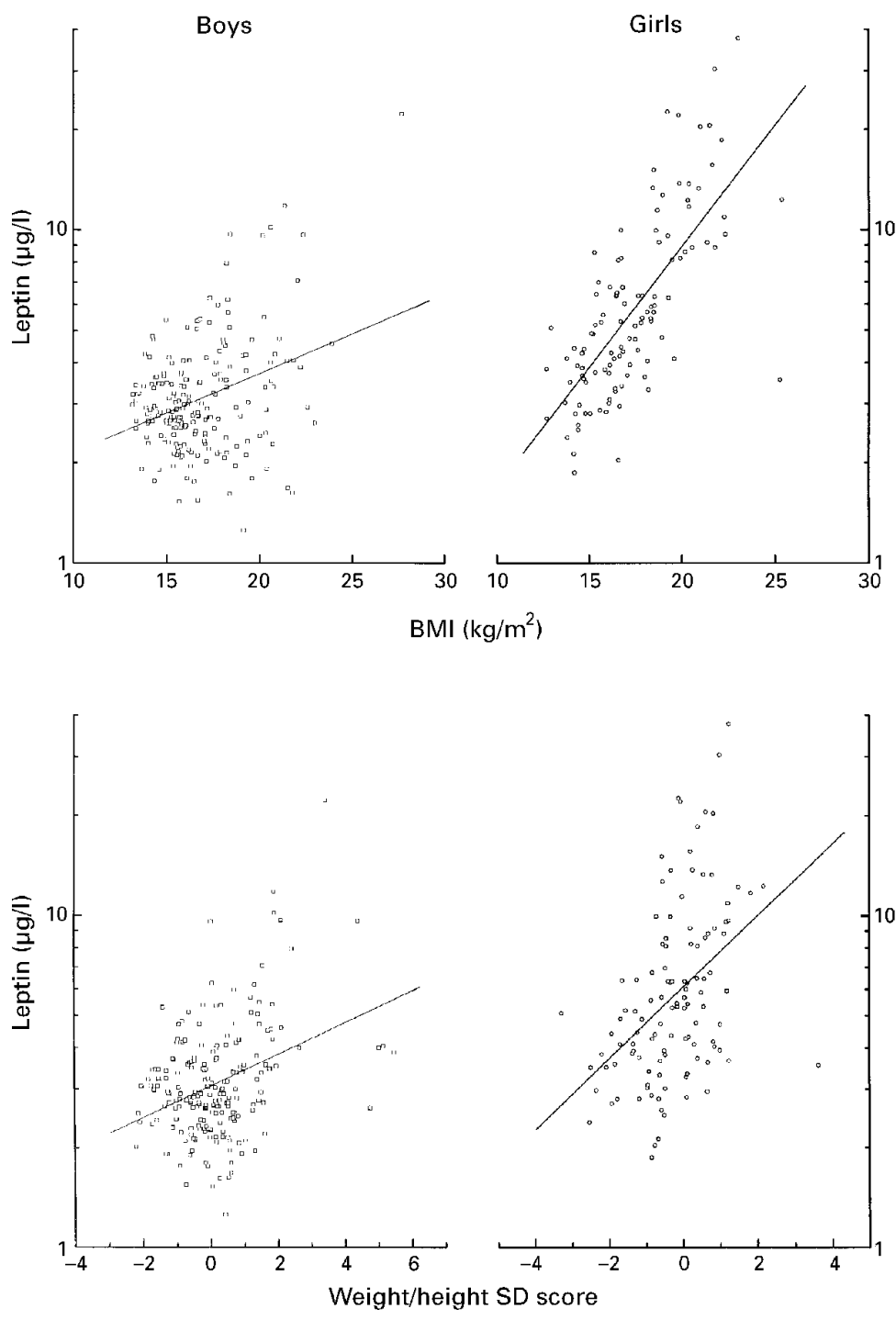

Figure 3 Serum leptin concentrations in boys and girls plotted against body mass index (BMI) (upper panels) and weight for height SD score (lower panels). Linear regression between BMI and leptin $\left(\log _{10}\right)$ resulted in $r=0.34$, mean (SE) slope $0.024(0.005)$ and intercept 0.09 (0.08), $n=203$ for the boys, and $r=0.71$, slope $=0.072(0.007)$ and intercept -0.50 (0.12), $n=113$ for the girls. Linear regression between weight for height $S D$ score and leptin $\left(\log _{10}\right)$ resulted in $r=0.36$, slope $0.048(0.009)$ and intercept 0.48 (0.01), $n=203$ for the boys, and $r=0.45$, slope 0.108 (0.021) and intercept 0.79 (0.02), $n=113$ for the girls.

\section{Results}

SERUM LEPTIN CONCENTRATIONS IN RELATION

TO AGE

Figure 2 shows serum leptin concentrations in healthy boys and girls of different ages. Serum leptin concentrations varied among subjects over approximately a 30-fold range. In girls linear regression showed that there was a positive correlation between serum leptin concentrations and age $(r=0.53$, mean (SE) slope 0.052 (0.008) and intercept $0.16(0.09), \mathrm{n}=113, \mathrm{p}<$ $0.0001)$. In contrast, there was no statistically significant correlation between serum leptin concentrations and age in the boys $(r=-0.09$, slope $-0.005(0.004)$ and intercept 0.55 (0.05), $\mathrm{n}=203, \mathrm{p}=0.2)$.

SERUM LEPTIN CONCENTRATIONS IN RELATION TO BODY COMPOSITION

To determine the relation between leptin and body composition, serum leptin concentrations were plotted against BMI (fig 3, upper panels) and weight for height SD score (fig 3, lower panels). There were significant correlations between serum leptin concentrations and the two measures of body composition in the two sexes, but the correlations were much stronger in the girls than in the boys.

\section{SERUM LEPTIN CONCENTRATIONS IN RELATION} TO PUBERTAL STAGE

Figure 4 shows serum leptin concentrations in boys and girls during puberty. In prepubertal children the serum leptin concentrations were in the same range in boys and girls (mean (SE) $3.5(0.1)$ and $4.5(0.4) \mu \mathrm{g} / \mathrm{l}$, respectively), even if they differed significantly ( $p<0.05)$. Girls and boys also differed in terms of changes during puberty. In girls the serum leptin concentrations increased during puberty, resulting in concentrations at pubertal stages 4 and 5 that were significantly higher than the levels in prepubertal girls $(p<0.001)$ and levels at stage 5 that significantly exceeded the levels of all other groups ( $\mathrm{p}<0.001)$. In marked contrast, serum leptin concentrations did not change with pubertal development in the boys. The changes in serum leptin concentrations during pubertal development persisted when leptin was corrected for $\mathrm{BMI}$.

In the girls, serum leptin concentrations were also expressed in relation to time from menarche (fig 5). Before menarche serum leptin concentrations were comparable with the prepubertal levels (mean (SE) 5.4 (0.5) and 4.5 (0.4) $\mu \mathrm{g} / \mathrm{l}$, respectively, NS), whereas there was a marked increase in serum leptin concentrations after menarche (13.7 (1.4) $\mu \mathrm{g} / \mathrm{l}, \mathrm{p}$ $<0.0001 v$ levels before menarche).

\section{Discussion}

This study shows that serum leptin concentrations increase during pubertal development in girls, whereas they remain constant in boys. The difference in serum leptin concentrations between boys and girls reflects changes in body composition that occur during puberty. A marked gender difference exists with an increase in fat mass in girls during the later stages of puberty. ${ }^{1}$ Previous studies have shown value was adjusted with the number comparisons to compensate for a mass significance effect. $^{20}$ value less than 0.05 was considered significant.

samples, one of which had been kept at $-70^{\circ} \mathrm{C}$ and the other stored at $-20^{\circ} \mathrm{C}$ for several years. before analysis, whereas four of the $-20^{\circ} \mathrm{C}$ been thawed or stored, or both, at $-20^{\circ} \mathrm{C}$ is 


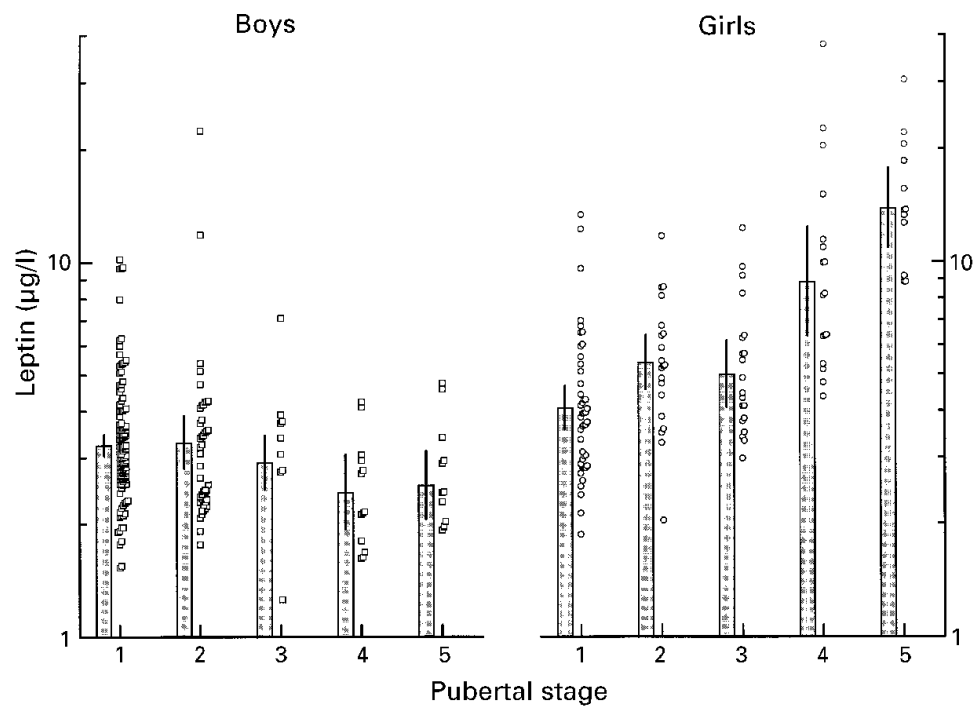

Figure 4 Serum leptin concentrations in boys and girls plotted against pubertal stage. The bars represent mean ( $95 \%$ confidence interval).

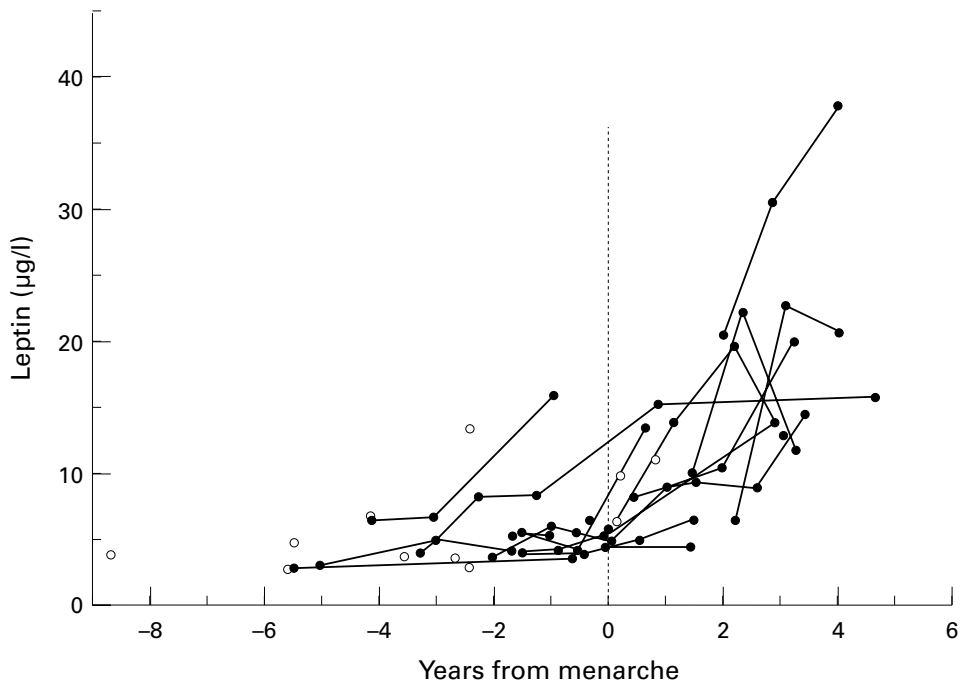

Figure 5 Serum leptin concentrations in girls in relation to time of menarche. Closed symbols with connecting lines represent observations in girls followed longitudinally $(n=15$, 52 observations) and open symbols represent single observations $(n=10)$.

that serum leptin concentrations correlate with BMI. ${ }^{1021}$ We also found such a correlation in this study; however, the gender difference in serum leptin concentrations during pubertal development was still present when corrected for BMI. This supports results from previous studies showing that a gender difference in serum leptin concentrations remains after correction for body fat in adults and children. ${ }^{11} 22$

It should be noted, however, that BMI may be a less precise indicator of body fat mass in growing children than in adults. The increase in body fat during adolescence in girls has been estimated to be approximately $120 \% .^{1}$ Based on the reported relation between serum leptin concentrations and body fat mass in several studies, an increase in body fat of $120 \%$ would lead to an approximately twofold increase in serum leptin concentrations. ${ }^{102122}$ It is therefore possible that the increase in serum leptin concentrations during pubertal development in girls may reflect this increase in body fat.

The importance of body fat for menarche and for normal reproduction, pregnancy, and lactation is well recognised. ${ }^{12}$ The link between adipose tissue and the reproductive system is unclear, however. The identification of the ob gene $^{3}$ and its adipocyte specific gene product, leptin, has provided a new clue to the mechanism by which the brain translates accumulated body fat into its regulation of the gonads. Recent experiments in mice have shown that leptin triggers the maturation of the reproductive tract and is required for the normal function of the reproductive system in females. ${ }^{7-9}$ These studies indicated that leptin may exert its effects directly or indirectly on neurons producing gonadotrophin releasing hormone $(\mathrm{GnRH})$ in the hypothalamus. As changes in the secretion of $\mathrm{GnRH}$ are believed to be a primary event in the hormonal regulation of puberty, ${ }^{24}$ we determined serum leptin concentrations in a large number of pubertal boys and girls. In the girls, serum leptin concentrations increased during pubertal development, with a two to threefold increase in serum leptin concentrations between pubertal stages 3 and $4-5$. The magnitude of this change in serum leptin concentrations in pubertal girls is more dramatic than the change seen during pubertal development in female mice, where a $60 \%$ increase has been reported. ${ }^{9}$ It should be noted, however, that significant differences may exist between rodents and humans with respect to leptin physiology-for example, there are known species differences in the diurnal pattern of serum leptin ${ }^{18}{ }^{25}$ and in the regulation of leptin by insulin. ${ }^{25} 26$ An alternative interpretation of the results in the present study may be that the increase in serum leptin concentrations is a consequence of pubertal development rather than a cause.

In contrast with the increase in serum leptin concentrations during pubertal development observed in the girls, serum concentrations of leptin remained constant during pubertal development in the boys. Mantzoros et al also found that leptin concentrations are similar in prepubertal and pubertal boys. ${ }^{27}$ In that study and in a preliminary report by Blum et al there was a transient increase in leptin concentrations just before the onset of puberty, ${ }^{28}$ which was not detected in our subjects. It has been shown that leptin is of importance for reproductive function in male mice ${ }^{29}$ and it is possible that a transient increase in serum leptin could be of importance for the initiation of puberty in boys.

Leptin is believed to act as an afferent satiety signal to the central nervous system and the administration of recombinant leptin reduces body weight in animals..$^{3-6}$ Obesity in children and adults results in increased serum concentrations of leptin and it has been suggested that these subjects are 'leptin resistant'. ${ }^{10}$ The increase in serum leptin concentrations found in pubertal girls in this study and in a study of pubertal development in mice ${ }^{9}$ suggests that a 'physiological leptin resistance', with respect to weight control, develops during puberty. An 
altered set point of the leptin system may provide a mechanism by which sufficient energy supplies are maintained to support a pregnancy.

In summary, we found a distinct gender difference in the pattern of serum leptin concentrations, with an increase during pubertal development in girls while the levels remained constant in boys. The increase in serum leptin concentrations during pubertal development in girls suggests that leptin may be the previously hypothesised link between adipose tissue and puberty in humans and rodents. The physiology of leptin in this context is likely to be complex, however, to allow an increase in body fat and at the same time generate a putative signal triggering puberty in girls.

We are grateful to the staff of ward $34 \mathrm{~T}$ for taking care of the patients. The study was supported by the Swedish Medical Research Council $(7509,11285,11502,11331,11576)$, the Swedish Society of Medicine, the Freeman Lodge, the Lundberg Foundation, and Pharmacia and UpJohn AB.

1 Frisch RE. The right weight: body fat, menarche and fertility. Proc Nutr Soc 1994;53:113-29.

2 Grumbach MM, Styne DM. Puberty: ontogeny, neuroendocrinology, physiology, and disorders. In: Wilson JD, Foster DW, eds. Williams textbook of endocrinology. ter DW, eds. Williams textbook

3 Zhang Y, Proenca R, Maffei M, Barone M, Leopold L, Zhang Y, Proenca R, Maffei M, Barone M, Leopold L, and its human homologue. Nature 1994;372:425-32.

4 Pelleymounter MA, Cullen JC, Baker MB, et al. Effects of the obese gene product on body weight regulation in ob/ob mice. Science 1995;269:540-3.

5 Halaas JL, Gajiwala KS, Maffei M, et al. Weight-reducing effects of the plasma protein encoded by the obese gene. Science 1995;269:543-6.

6 Campfield LA, Smith FJ, Guisez Y, Devos R, Burn P. Recombinant mouse OB protein: evidence for a peripheral signal linking adiposity and central neural networks. Science 1995;269:546-9.

7 Chehab FF, Lim ME, Lu R. Correction of the sterility defect in homozygous obese female mice by treatment with human recombinant leptin. Nat Genet 1996;12:318-20.

8 Ahima RS, Prabakaran D, Mantzoros C, et al. Role of leptin in the neuroendocrine response to fasting. Nature 1996; in the neur: $250-2$.

9 Chehab FF, Mounzih K, Lu R, Lim ME. Early onset of reproductive function in normal female mice treated with reproductive function in normal

10 Considine RV, Sinha MK, Heiman ML, et al. Serum immunoreactive-leptin concentration in normal-weight and obese humans. N Engl f Med 1996;334:292-5.
11 Hassink SG, Sheslow DV, Lancey E de, Opentanova I, Considine RV, Caro JF. Serum leptin with obesity: relationship to gender and development. Pediatrics 1996;98:201-3.

12 Bray GA. Leptin and leptinomania. Lancet 1996;348:140.

13 Tanner JM, Whitehouse RH. Clinical longitudinal standards for height, weight, height velocity, weight velocity and stages of puberty. Arch Dis Child 1976;51:170-9.

14 Zachmann M, Prader A, Kind HP, Häflinger H, Budlinger $\mathrm{H}$. Testicular volume during adolescence. Cross-sectional and longitudinal studies. Helv Pcediatr Acta 1974;29:61-72.

15 Karlberg J, Taranger J, Engström I, Lichtenstein H, Svennberg-Redegren I. The somatic development of children in a Swedish urban community. Acta Pcediatr Scand Suppl 1976;258:1-88.

16 Albertsson-Wikland K, Rosberg S, Karlberg J, Groth T. Analysis of 24-hour growth hormone $(\mathrm{GH})$ profiles in healthy boys and girls of normal stature. II. Relation to puberty. F Clin Endocrinol Metab 1994;78:1195-201.

17 Hammer T, Kreamer H, Wilson D, Ritter P, Dornbusch S. Standardized percentile curves of body-mass index for children and adolescents. Am 7 Dis Child 1991;145:259-63.

18 Sinha MK, Ohannesian JP, Heiman ML, et al. Nocturnal rise of leptin in lean, obese, and non-insulin-dependent diabetes mellitus subjects. $\mathcal{F}$ Clin Invest 1996;97:1344-7.

19 Rodbard D. Statistical estimation of minimum detectable concentration ('sensitivity') for radioligand assays. Anal Biochem 1978;90:1-12.

20 Altman DG. Practical statistics for medical research. London: Chapman and Hall, 1995.

21 Maffei M, Haalas J, Ravussin E, et al. Leptin levels in humans and rodents-measurement of plasma leptin and ob RNA in obese and weight-reduced subjects. Nat Med 1995;1:1155-61.

22 Rosenbaum M, Nicolson M, Hirsch J, et al. Effect of gender, body composition, and menopause on plasma concentrations of leptin. 7 Clin Endocrinol Metab 1996;81:3424-7.

23 Dua A, Hennes MI, Hoffmann RG, et al. Leptin: a significant indicator of total body fat but not visceral fat and insulin insensitivity in African-American women. Diabetes 1996;45:1635-7.

24 Odell WD. Endocrinology of sexual maturation. In: DeGroot LJ, Besser M, Burger HG, et al, eds. Endocrinology. Vol 2. Philadelphia: Saunders, 1995;1938-52.

25 Saladine R, De Vos P, Guerre-Millo M, et al. Transient increase in obese gene expression after food intake or insulin administration. Nature 1995;377:527-9.

26 Kolaczynski JW, Nyce MR, Considine RV, et al. Acute and chronic effect of insulin on leptin production in humans. Diabetes 1996;45:699-701.

27 Mantzoros CS, Flier JS, Rogol AD. A longitudinal assessment of hormonal and physical alterations during normal puberty in boys. V. Rising leptin levels may signal the onset of puberty. F Clin Endocrinol Metab 1997;82: 1066-70.

28 Blum WF, Englaro P, Juul A, et al. Serum leptin levels in healthy children and adolescents [abst]. Horm Res 1996; 46(suppl 2):262.

29 Mounzih K, Lu R, Chehab FF. Leptin treatment rescues the sterility of genetically obese ob/ob males. Endocrinology 1997;138:1190-3. 